\title{
運動様式の異なる一過性運動が中年女性の気分に及ぼす影響 一ボクシングとヨガを取り入れた運動プログラムの場合
}

Impact of acute exercise on the mood in middle-aged women

- A comparative study of the boxing exercise and yoga exercise-

\section{早川 洋子 ${ }^{1}$, 大熊 慶 ${ }^{2}$ 高橋 裕子 $^{2}$, 内海 舞香 $^{3}$}

1 東京国際大学人間社会学部， 2 東京国際大学人間社会学部人間スポーツ学科専攻

3東京国際大学人間社会学部スポーツ科学科専攻

Yohko Hayakawa $^{1}$, Kei Okuma ${ }^{2}$, Yuko Takahashi², and Maika Utsumi ${ }^{3}$

${ }^{1}$ Faculty of human and social sciences, Tokyo International University

2509 Matoba, Kawagoe, Saitama, Japan 350-1198

2 Department of human development and sport sciences, Student of human and social sciences, Tokyo International University

2509 Matoba, Kawagoe, Saitama, Japan 350-1198

${ }^{3}$ Department of sport sciences, Student of human and social sciences, Tokyo International University 2509 Matoba, Kawagoe, Saitama, Japan 350-1198

$$
\text { キーワード : ボクシングエクササイズ, ヨガエクササイズ, POMS }
$$

Key words : Boxing exercise, Yoga exercise, Profile of Mood States（POMS）

\begin{abstract}
一抄録
本研究は，ボクシングエクササイズ（BE）とヨガエクササイズ（YE）の実施が気分（POMS）に 対してどのような急性の心理的影響をもたらすかを明らかにすることを目的として実施した. 対象者 は，T 市立体育館のフィットネスプログラムである BE プログラムもしくは YE を取り入れたプログ ラムのいずれかの教室に自主的に参加している中年女性 40 名（各プログラム 20 名）であった. 両教 室ともに各運動プログラムを 60 分間実施した. 対象者の気分については, 1 回の教室の運動実施の 前後において，短縮版の Profile of Mood States（POMS）を用いて評価を行った．すなわち，各運動プ ログラムの気分に対する急性の影響については, POMS の(「緊張一不安」「抑うつ一落ち込み」「敵 意」「活気」「疲労」「混乱」）6つの各下位尺度の運動前後の值について Wilcoxon 検定による群内比 較を行った. 群間の気分の変化の違いについては, 各下位尺度について, 運動前から運動後の変化量 を目的変数, 各運動プログラム群を説明変数, 運動前の值, 年齢, BMI を共変量とした共分散分析 を行った. その結果, BE 群の運動前後の気分については,「緊張一不安」,「抑うつ一落ち込み」の下 位尺度において有意なポジティブな変化が認められたが，その他の項目には有意差を認めなかった。 一方, YE 群の運動前後の気分については, 「緊張一不安」,「抑うつ一落ち込み」,「怒り一敵意」,「活 気」，「混乱」において有意なポジティブな変化が認められた．また，BE 群と YE 群の気分の変化の 違いについて検討した結果,「怒り一敵意」のみに有意な差が認められ，BE群でネガティブな変化で あったのに対して，YE群ではポジティブな変化が認められた。

以上のことから, 運動様式 (動的, 静的) の異なる 2 つ運動プログラムは共に中年女性の気分に 急性の変化をもたらすが，その変化の内容は運動強度や運動様式により異なることが示唆された.
\end{abstract}

\section{I . 緒言}

近年，精神疾患の患者数が増加しており，平成 11 年の精神疾患患者数は 204 万人であったが, 平
成 23 年には 320 万人となっている。 なかでも，う つ病患者の著しい増加がみられ，平成 11 年は 44 万人であったものが，平成 23 年には 96 万人と 2 
倍以上に増えている ${ }^{[1]}$ 。このような状況を踏まえ， 第 2 次健康日本 21 の国民の健康増進の推進に関す る基本的な方向において，社会生活を営むために 必要な機能を維持するうえで重要なものとして心 の健康を挙げ，自殺者の減少，重い抑榃や不安の 低減などを目標とし，そのためにメンタルヘルス 対策の充実などの取り組みを進めることとしてい $ろ^{[2] .}$

健康づくりの重要な分野である運動・身体活動 は, 虚血性心疾患 ${ }^{[3]}$, 脳血管疾患 ${ }^{[4]}$, 悪性新生物 (乳 がんや結腸がん等）[5]などの生活習慣病のリスク 低減といった効果に加え，最近，メンタルヘルス の改善やストレス対処などの精神的な機能の改善 にも有効である可能性が報告されている[6].これ らの精神機能に対する運動効果を得るためには, 適切な運動（身体活動）を長期継続して実施する ことが必要であり，運動の特性や個人のニーズを 踏まえた運動プログラムの開発が必要となる。近 年, スポーツクラブのスタジオプログラムとして, 様々なグループエクササイズが提供されるように なってきた. 特に 2000 年頃より, 従来から行なわ れてきたエアロビックダンスに加え，ヒップホッ プ系や格闘技系のカーディオエクササイズやボデ ィーワーク，およびボディーマインド系と呼ばれ るヨガを取り入れたエクササイズ，ピラティスと いった非カーディオ系の筋コンディショニングプ ログラムが多く実施されるようになってきた ${ }^{[7][8] . ~}$ その中でも最近，ボクシングの動きをベースとし た有酸素性運動プログラムであるボクシングエク ササイズ（BE）と筋のストレッチングを中心とし た静的な運動であるヨガを取り入れた運動プログ ラムが多く実施されるようになってきた。 BE は， ボクシングの動きを取り入れ，楽しく音楽に合わ せながら行うことができる有酸素性のエクササイ ズであり，エアロビクスの効果だけでなく，ス卜 レス解消の効果も期待される。また，ヨガを取り 入れた運動プログラム（フィットネス用に改良さ れたもの，以下，ヨガエクササイズ YE）の場合は 近年になって，主に先進国において一般人の健康 法として，急速に実施されるようになった運動プ ログラムであり [9]，身体と呼吸の動きを使って 様々なポーズを行い，意識を自然な形で身体と精 神へ向けるようにすることを目的としている ${ }^{[10] .}$ しかしながら，これらの運動による心理的症状に 対する影響についての検討はほとんど行われてい
ない. 特に，心理的な変化は，短期的もしくは単 発の運動刺激による急性的な変化として生じる可 能性があるが，これらの運動による心理症状に対 する急性的な影響についてはほとんど検討されて いない状況にある. BE プログラムについては，熊 原ら ${ }^{[11]}$ の報告のみであり，壮・中年の男女 16 名を 対象に，ボクシングのシャドーイングを中心とし たプログラムとミット打ちをシャドーイングに組 み入れたプログラムについて比較検討している. その結果，両プログラム共に心理的にネガティブ な側面を改善させ，快感情やリラックス感などの 精神的にポジティブな側面を向上させる急性効果 を報告している。一方，ヨガについては，長期的 な実践によりリラクゼーション効果，血行改善， ホルモン分泌機能，免疫機能の改善といった心理 的および生理的な効果が得られることが報告され ている[9][12]が，一過性の運動による心理的症状に ついては, 著者の知る限り報告はなされていない.

以上のように，BE や YE の運動プログラムが心 理的症状に及ぼす急性的な影響について検討した ものはいまだ報告が少ない．特に，動的な運動で ある $\mathrm{BE}$ と静的な運動である YEという運動様式が 大きく異なる運動プログラムの心理的症状に対す る急性的な影響について比較検討した研究は著者 が知る限りいまだない。そこで本研究は，BEプロ グラムと YE プログラムを実施した際の，心理的 症状に対する急性的な影響について検討するとと もに，両プログラムの影響の違いについても明ら かにすることを目的とした。

\section{II. 方法}

\section{1. 対象者}

対象者は，群馬県下の $\mathrm{T}$ 市の地域総合型スポー ツクラブが地域の NPO 法人に委託して実施した 健康づくり教室の $\mathrm{BE}$ または YEの教室に自主的に 参加した 40-50 歳代の中年女性 40 名（各プログラ ム 20 名）であった。 なお，本研究については，対 象者に対して研究の目的や方法などを事前に説明 して同意を得ること，および無記名の調査のみを 行うことから，倫理審査不要として実施した。

\section{2. 調査の方法と内容}

本調査は, 2016年9月の第 2 週の教室において, 運動プログラムの実施前と実施後の 2 回行った. 調査は質問紙による自記方式で行った。 
調査項目は，身体特性として年齢，身長，体重 とし，身長と体重から Body Mass Index(BMI)を算 出した。 心理的症状は,「気分」について, 短縮版 の Profile of Mood States（POMS） [13]により測定を 行った. POMS は 6 つの気分尺度である「緊張一 不安」「抑うつ一落ち込み」「敵意」「活気」「疲 労」「混乱」で構成され，回答者がおかれた条件に よって変化する一時的な気分や感情の変化が測定 でき，実施した運動等の効果が評価できるとされ ている ${ }^{[13]}$. なお, 気分とは主観的な印象で, 快不 快を基調とし，喜びと悲しみ，苦しさと楽しさな ど相反する二極性を持つ感情の持続的な状態とし て定義されている. 気分が正常の範囲を超えて高 揚したり，落ち込んだりすることが，一定の期間 継続する場合は気分障害となり，その代表的な疾 患がうつ病と, 躁うつ病とされている[14].

\section{3. 教室および運動プログラム}

各運動教室は，1 回当たり運動時間は 60 分であ り，教室は 1 週間に 1 回の頻度で，年間を通して 開催された. 教室への参加は随時受け付けられた.

BE プログラムの教室では, まず基本的な動作に ついて説明と練習を行い，対象者が動作を理解で きたことを確認した上で，実際の運動プログラム を行った。プログラムは，ジャブパンチの直後に 連動してストレートパンチを放つワンツー・パン チなど単純なコンビネーション技術から導入され， 初心者向けのステッピングやウィービング（相手 に的を絞らせないようにするための頭・上体を左 右に動かす動作）やダッキング（膝を沈ませ頭・ 上体を上下しパンチをかわす動作）といった防御 技術を組み合わせたコンビネーション技術へ展開 されるプログラムであった.

YE のプログラムは，まず，全身の筋肉をじっく り伸ばし，股関節・首関節・肩関節などの大きな 関節をゆっくりまわしてほぐす動きを実施した。 その際は，呼吸は止めずに楽に続けるように指示 した。 その後, 両腕を上に挙げたポーズや立位体 前屈のポーズなど基本的なポーズを繰り返し行い, その後は座位になって目を閉じ，数分間の瞑想を 行った。最後に，全身のストレッチングを行い終 了した.

各運動プログラムの内容構成および実技指導は 熟練したインストラクターにより行われた.

\section{4. 統計解析}

身体的特性の各項目についてのBE群と YE 群の 比較については，対応のない $\mathrm{t}$ 検定を用いた。ま た，両群の運動実施前の POMS の下位尺度の各項 目について，両群の平均值の有意差検定を Mann-Whitney Test（U 検定）により実施した.

各運動プログラムの気分に対する急性の影響に ついては，POMS の各下位尺度の運動前後の值に ついてWilcoxon検定法を用いて群内比較を行った。 群間の気分の変化の違いについては，各下位尺度 の運動前の平均值に群間差が認められたことから， 運動前から運動後の変化量（運動後一運動前）を 目的変数, 各運動プログラム群を説明変数, 目的 変数の運動前の值，年齢，BMI を共変量とした共 分散分析を行った.

統計解析には SPSS（IBM SPSS Statics 23）を用 い，危険率 5\%未満を有意差ありとした。

\section{III. 結果}

\section{1. 対象者の身体的特性}

各群における対象者の身体的特性 (年齢, 身長, 体重，BMI）を表 1 に示した。各項目ともに両群 間に有意差は認められなかった。

表 1 対象者の身体的特性

\begin{tabular}{|ll|c|c|c|c|}
\hline & & $\begin{array}{c}\text { 全体 } \\
(\mathrm{n}=40)\end{array}$ & $\begin{array}{c}\text { BE群* } \\
(\mathrm{n}=20)\end{array}$ & $\begin{array}{c}\text { YE群** } \\
(\mathrm{n}=20)\end{array}$ & $\begin{array}{c}\text { 有意確率 } \\
(\mathrm{p}) \#\end{array}$ \\
\hline 年齢 & $($ 歳 $)$ & $50.0 \pm 6.2$ & 51.244 .5 & $48.8 \pm 7.3$ & 0.231 \\
身長 & $(\mathrm{c} \mathrm{m})$ & $159.0 \pm 0.1$ & $159.6 \pm 0.1$ & $158.4 \pm 0.1$ & 0.545 \\
\hline 体重 & $(\mathrm{k} \mathrm{g})$ & $55.9 \pm 7.8$ & $56.7 \pm 9.3$ & $55.2 \pm 5.9$ & 0.556 \\
\hline BVI & $\left(\mathrm{k} \mathrm{g} / \mathrm{m}^{2}\right)$ & $22.2 \pm 3.3$ & $223+3.6$ & $221 \pm 29$ & 0.870 \\
\hline
\end{tabular}

\# : 対応のない $\mathrm{t}$ 検定, * $\mathrm{BE}$ :ボクシングエクササイズ **YE:ヨガエクササイズ

\section{2. 運動前の気分の群間比較}

各群の運動前における POMS 下位尺度の各項目 の結果を表 2 に示した。その結果，「緊張一不安」 $(\mathrm{P}=0.020)$ と「怒り一敵意」 $(\mathrm{P}=0.017)$ において両 群間にいずれも有意差が認められ，いずれの項目 とも YE 群が BE 群よりも高い值を示した. その他 の項目については，両群間に有意差は認められな かった. 
表 2 ボクシングエクササイズ群とヨガ群の運動前の気分の比較

\begin{tabular}{|c|c|c|c|c|c|}
\hline & \multicolumn{5}{|c|}{ 運動前 } \\
\hline & \multicolumn{2}{|c|}{ BE群 $\quad(n=20) *$} & \multicolumn{2}{|c|}{ YE群 $(\mathrm{n}=20) * *$} & \multirow{2}{*}{$\begin{array}{c}\text { 有意確率 } \\
(\mathrm{p}) \#\end{array}$} \\
\hline & 平均值 & 標準偏差 & 平均值 & 標準偏差 & \\
\hline 緊張一不安 & 3.400 & 6.394 & 5.650 & 4.966 & 0.020 \\
\hline 抑うつ一落ち込み & 2.450 & 3.993 & 4.250 & 4.962 & 0.244 \\
\hline 怒り一敵意 & 2.500 & 4.513 & 5.900 & 4.951 & 0.017 \\
\hline 活気 & 9.150 & 5.788 & 8.500 & 4.861 & 0.989 \\
\hline 疲労 & 4.450 & 4.861 & 5.850 & 5.509 & 0.334 \\
\hline 混乱 & 4.050 & 2.911 & 5.850 & 3.703 & 0.058 \\
\hline
\end{tabular}

\# : Mann-Whitney Test (U 検定),

* $\mathrm{BE}$ : ボクシングエクササイズ，＊* YE : ヨガエクササイズ

\section{3．運動実施前後の気分変化の群内比較}

各群の運動実施前後における POMS の各下位尺 度の結果を表 3 に示した。BE群では，「緊張一不 安」 $(\mathrm{P}=0.003)$ と「抑うつ一落ち込み」 $(\mathrm{P}=0.008)$, において，いずれも有意なポジティブな変化が認 められた。しかし，その他の下位尺度には有意な 変化は認められなかった。

YE 群では，「緊張一不安」 $(\mathrm{P}=0.001)$,「抑うつ 一落ち込み」 $(\mathrm{P}=0.004)$,「怒り一敵意」 $(\mathrm{P}=0.001)$ ， 「活気」 $(\mathrm{P}=0.018)$,「混乱」 $(\mathrm{P}=0.003)$ において, いずれも有意なポジティブな変化が認められた.

\section{4. 運動実施前後の気分変化の群間比較}

運動実施前後の気分変化についての群間の比較 を行った結果を表 4 に示した。その結果，「緊張一 不安」と「抑うつ一落ち込み」については両群と もに同様な変化であり，群間差は認められなかっ た。しかし，「怒り一敵意」の項目においては，BE 群ではネガティブな変化（+1.6）であったのに対
して，YE群ではポジティブな変化（－5.0）であ り，両群間に有意な差が認められた。 その他の下 位尺度には，有意な差は認められなかった。

\section{IV. 考察}

本研究は，中年女性を対象として，運動様式（動 的, 静的）の異なる BEと YEの実施が気分に対し てどのような急性の影響をもたらすかを明らかに することを目的として実施した。その結果，両運 動プログラムは共に気分に急性の変化をもたらす が，その変化の内容は運動特性により異なること が示唆された。このように，運動様式が異なる運 動プログラムによる心理的症状（気分）への急性 的な影響について比較検討した研究はこれまで報 告されていないことから，本研究結果は運動様式 の違いによる気分への急性的な影響の違いを示し た点で意義のあるものと考えられる.

運動が心理的要因に与える急性の影響について 検討した研究がこれまでにいくつか報告されてい

表 3 ボクシングエクササイズ群とヨガ群の運動前後の気分の比較

\begin{tabular}{|c|c|c|c|c|c|c|c|c|c|c|}
\hline & \multicolumn{4}{|c|}{ BE群 $\quad(n=20) *$} & & \multicolumn{5}{|c|}{ YE群 $\quad(n=20) * *$} \\
\hline & \multicolumn{2}{|c|}{ 前 } & \multicolumn{2}{|r|}{ 後 } & \multirow{2}{*}{$\begin{array}{c}\text { 有意確率 } \\
(\mathrm{p}) \#\end{array}$} & \multicolumn{2}{|r|}{ 前 } & \multicolumn{2}{|c|}{ 後 } & \multirow{2}{*}{$\begin{array}{c}\text { 有意確率 } \\
\text { (p)\# }\end{array}$} \\
\hline & 平均值 & 標準偏差 & 平均值 & 標準偏差 & & 平均值 & 標準偏差 & 平均值 & 標準偏差 & \\
\hline 緊張一不安 & 3.40 & 6.39 & 0.40 & 1.27 & 0.003 & 5.65 & 4.97 & 1.55 & 2.96 & 0.000 \\
\hline 抑うつ一落ち込み & 2.45 & 3.99 & 0.40 & 0.94 & 0.008 & 4.25 & 4.96 & 1.25 & 2.51 & 0.004 \\
\hline 怒り一敵意 & 2.50 & 4.51 & 4.10 & 2.63 & 0.069 & 5.90 & 4.95 & 0.90 & 2.31 & 0.001 \\
\hline 活気 & 9.15 & 5.79 & 9.40 & 5.38 & 0.652 & 8.50 & 4.86 & 10.45 & 5.68 & 0.018 \\
\hline 疲労 & 4.45 & 4.86 & 6.25 & 5.32 & 0.153 & 5.85 & 5.51 & 4.55 & 4.54 & 0.422 \\
\hline 混乱 & 4.05 & 2.91 & 3.65 & 2.54 & 0.750 & 5.85 & 3.70 & 3.55 & 2.58 & 0.003 \\
\hline
\end{tabular}

\#:Wilcoxon 検定， *BE:ボクシングエクササイズ，**YE:ヨガエクササイズ 
表 4 ボクシングエクササイズ群とヨガエクササイズ群における気分の変化についての群間比較

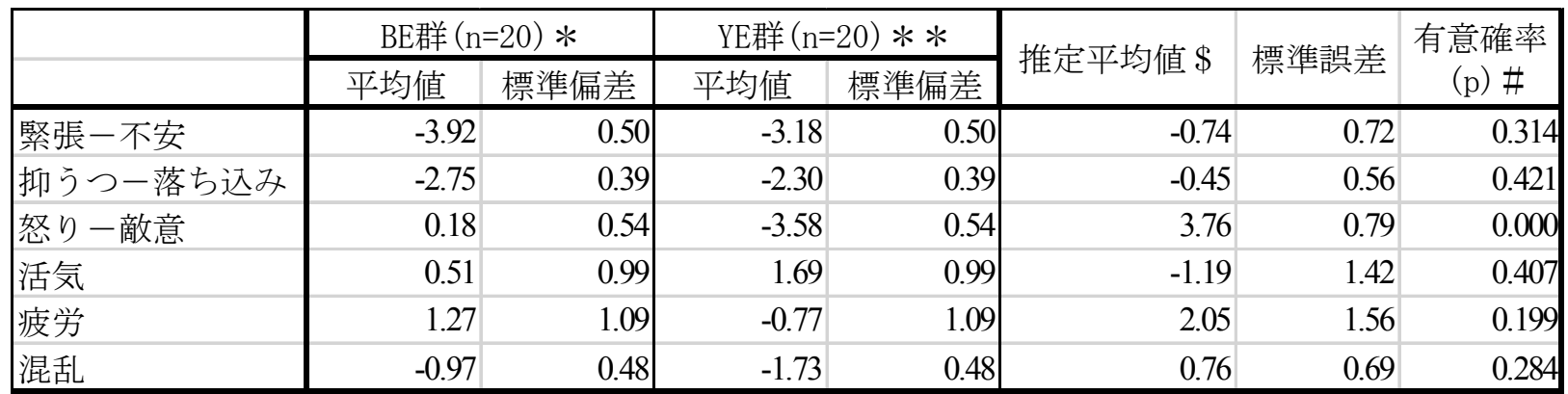

\# : 共分散分析 (各運動の実施前の值，年齢，BMI で調整)，＊BE：ボクシングエクササイズ，**YE：ヨガエクササ

イズ $\$:$ 運動後一運動前の変化量の推定平均值

る[15][16][17][18][19][20].これらの研究のほとんどは有酸 素性の運動であり，実験室の環境下で行われてい るものが多い. 本研究で用いた BE は有酸素性運 動として実施されているが，その心理的要因に関 する急性的な影響については，熊原らの報告があ るのみで，ほとんど検討されていない。熊原ら ${ }^{[11]}$ は, 休憩を含み約 50 分間のボクシングの運動様式 を応用した一過性の運動で, POMS の「緊張一不 安」,「抑うつ一落ち込み」,「怒り一敵意」,「活気」, 「混乱」の項目において，有意にポジティブな変 化が認められた，としている. 本研究の BE 群で は，「緊張一不安」，「抑うつ一落ち込み」において は熊原らの結果と同様なポジティブな変化が認め られたが，「怒り一敵意」，「活気」，「疲労」，「混乱」 については有意な変化は認められなかった。さら に，「怒り一敵意」に関しては，本結果では有意で はないが,むしろネガティブな変化が認められた。 このように，本結果は熊原らの結果と異なるもの であったが，その違いをもたらした要因について は，必ずしも明らかではない. Ekkekakisand et al. （1999）[21]は，一過性の有酸素性運動と感情に関 する研究についてレビューを行い，中等度の運動 は「活気」や「高揚感」を増加し，「緊張」や「緊 張一不安」といったネガティブ感情を低下させる としている。また，高強度で長時間の運動は，「緊 張」,「不安」,「疲労」などのネガティブな感情を 引き起こすとし, 感情に対する運動の影響は運動 強度により異なるとしている。このレビュー結果 を踏まえると，熊原らが用いた運動強度と本研究 での運動強度が異なっていた可能性が考えられる。 本研究では，BEの運動強度は測定していないが， $\mathrm{BE}$ の運動強度は同じグループエクササイズのエ アロビックダンスと類似していることから ${ }^{[8]}$ ，本
研究における BE の運動強度は 7.0-7.9 Mets 程度

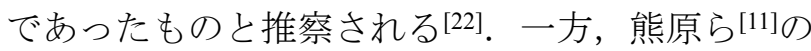
研究では，運動時の心拍数を測定しており，運動 時平均心拍数は 130.5 拍/分であったと報告してい る。したがって，彼らの研究で用いた BE の運動 強度は中等度であったものと思われる。また，熊 原らの研究対象者は平均年齢が 35 歳と, 本研究対 象者（平均年齢 51.2 歳）に比べて若いことから, 運動に対する耐容力が高いものと推察される。こ れらのことから, 熊原らの研究における $\mathrm{BE}$ の強 度は本研究の運動強度よりも低いものであった可 能性があり，多くの項目においてポジティブな変 化が認められたものと思われる。それに対して, 本研究における BE は対象者にとって比較的高い 強度であったことが予想され，そのために運動後 に有意ではないが「疲労」が増加 $(+1.8)$ し，「怒 り一敵意」にネガティブな方向への変化が生じた 可能性がある。このことに関して，本研究の BE 群の対象者は，内省報告で $80 \%$ の人が体力的につ いていけないことがあった (未掲載資料)，と回答 していたことからも，その可能性が示唆される.

YEに関しては，中・長期的なトレーニングの心 理的症状に関する効果についてはいくつかの報告 があるが，それらは対照群が設定されていないな ど研究デザインに問題があるものが多い.

Yoshihara et al. (2014) ${ }^{[23]}$ は，20-50 歳の健康な女性 に 12 週間の YEのトレーニングを行っている.そ の結果, YE 群では「緊張一不安」,「怒り一敵意」,

「抑うつ一落ち込み」「疲労」などのネガティブな 心理的症状に対して，対照群に比べて改善効果が 認められたと報告している。このような心理的症 状は，比較的短期的にも変化することから，トレ ーニングによる長期的な刺激に対する適応として 
の変化であるかについては慎重な検討が必要とな る. 本研究では，単発のYEを行った時の心理的 症状 (気分) に対する急性変化について検討した。 このような一般の中年女性を対象として, YEによ る気分に対する急性の影響を検討した研究はこれ まで著者の知る限り報告されていない，本研究の 結果，YE 群は，一過性の運動であったにもかかわ らず, Yoshihara et al. (2014) ${ }^{[23]}$ と同様な結果を示し, 「緊張一不安」,「抑うつ一落ち込夕」, 「怒り一敵 意」,「混乱」といったネガティブな心理的症状の 項目において有意な改善的変化を示した。これら の結果が得られた理由に関しては必ずしも明らか ではないが，YEの運動強度が 2.0-2.9mets の低強 度であったことや[22], YE は運動中においては意識 を身体や呼吸に集中寸るために，緊張した身体を リラックスさせる効果があると報告されており [9], これらのことが本結果に関係している可能性が考 えられる。

運動による気分に対する急性の影響については, 運動種目の違いによる影響がある可能性が示唆さ れている。竹中ら ${ }^{[19]}$ れ，自転車エルゴメーターを 用いた運動の心理的症状に対する急性の影響につ いて検討した結果，POMS の「緊張一不安」およ び「怒り」の項目において得点が有意に低下した が，その他の項目では有意な変化は認められなか ったとしている。一方，牛島ら ${ }^{[20]}$ は，エアロビッ クダンス, 水泳, ゴルフ, 卓球, ニュースポーツ, ウォーキングなど数種類の有酸素性運動による急 性の精神的影響について検討した結果，いずれの 運動種目も気分をポジティブに好転させる効果が あったとしている。このように運動種目の違いに よる心理的症状に対する急性の影響については異 なる結果が報告されている。これらの研究で用い られている運動はいずれも有酸素性の運動である ことから，それらの心理的症状に対する影響はそ れほど大な違いはない可能性も考えられる.

そこで本研究では, 運動様式が大きく異なる $\mathrm{BE}$ （動的運動）と YE（静的運動）による心理的症状 （気分）に対する急性の影響の違いについて比較 検討した。その結果，「緊張-不安」と「抑うつ一 落ち込み」の項目では両群ともにポジティブな変 化が見られ，その変化の程度に有意差はなかった。 また，「活気」と「混乱」については YE 群のみに 有意なポジティブな変化が認められたが，両群間 にその変化の程度に有意な差はなかった。しかし，
「怒り一敵意」の項目においては，その変化の方 向は BE 群ではネガティブ（+1.6）であったのに 対して，YE 群ではポジティブ $(-5.0)$ であり, 全く逆の変化が認められた（表 4)。その結果，両 群間において, 運動の影響に有意差が認められた。 このような気分の下位尺度に対する運動の影響に 異なるパターンが示された理由としては，一つに は，両運動プログラムの運動強度の違いが反映さ れた可能性が考えられる.前述した Ekkekakisand et al.（1999）[21]のレビューの結果を踏まえると，本 研究の両運動プログラムにおいては，前述したよ うに運動強度に違いがあった可能性が推察され， そのことにより POMS の各項目の変化のパターン に違いが生じたものと思われる．また，もう一つ の理由として，運動の様式や内容の違いが反映さ れた可能性が考えられる。すなわち，BE プログラ ムはボクシングの動作を基に作成されており，相 手に対する打撃や相手の打撃をかわす動作を中心 として構成されている。したがって，BE プログラ ムを実施することにより，このような動作を通じ て相手に対する闘争的な感情が無意識的に強くな る可能性が考えられる。一方，YE プログラムは関 節の可動化や筋肉のストレッチングなどの動作を 中心として構成されており，このような動作は緊 張した身体をリラックスさせる効果があるとされ

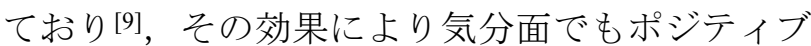
な影響が生じたものと推察される。ささらに，この プログラムでは，呼吸法や瞑想法なども取り入れ たものとなっており，それらの効果が本結果の気 分プロフィールに反映された可能性もある.

本研究の限界としては，まず，本研究では，対 象者が運動プログラムを実施している際の心拍数 を計測していないことから，各運動プログラムの 運動強度を正確に評価できなかった。したがって， 両運動プログラムの運動強度にどの程度の違いが あるかについては，これまでの資料などを基に推 定せざるを得なかった，次に，本研究の対象者は 各群 20 名であり，質問紙による主観的評価值であ る POMS の下位尺度の測定值の変化を十分に検出 するには問題がある可能性がある。また，各群の 対象者は，各自が任意にプログラムを選択してお り，無作為に割り付けられなかったことから，両 群間に何らかのバイアスが生じている可能性があ る. 


\section{V. まとめ}

本研究は，中年女性を対象として，ボクシング エクササイズ (BE) とヨガエクササイズ ( $\mathrm{YE})$ と いう運動様式の大きく異なる運動プログラムを実 施した際の，心理的症状（気分プロフィール） の急性的な影響について検討した。 その結果, $\mathrm{BE}$ 群は, 「緊張一不安」と「抑うつ一落ち込み」の項 目で有意な改善的な変化が認められた。一方, YE 群では, 「緊張一不安」,「抑うつ一落ち込み」,「怒 り一敵意」,「活気」,「混乱」の項目で有意な改善 的な変化が認められた。 これらの変化について群 間比較を行ったところ，「緊張一不安」と「抑うつ 一落ち込み」については両群とも同様な変化であ ったが，「怒り一敵意」では BE 群ではネガティブ な変化であったのに対して, YE 群ではポジティブ な変化であり，両群間で異なる変化が認められた。 このような両群間の気分プロフィールの変化の違 いは，両プログラムの運動強度と運動の様式や内 容の違いが反映されたものと推察された。

\section{VI. 謝辞}

本研究の趣旨を理解し, 快く協力して頂きまし た $\mathrm{T}$ 市の体育館のスタッフや調査対象者の皆様に 心から感謝申し上げます。

\section{VII. 参考文献}

[1] 知ることからはじめようみんなのメンタルヘ ルス.

http://www.mhlw.go.jp/kokoro/speciality/data.html, (参照 2016-12-31).

[2] 運動基準・運動指針の改定に関する検討会 報 告書.

http://www.mhlw.go.jp/stf/houdou/2r9852000002xpleatt/2r9852000002xpqt.pdf, (参照 2016-12-31).

[3] Sattelmair, J et al. Circulation. Dose response BEtween physical activity and risk of coronary heart disease: a meta-analysis. Circulation. 2011, 16; 124(7), p.789-95.

[4] Diep, L et al. Association of physical activity level and stroke outcomes in men and women: a meta-analysis. J Womens Health (Larchmt). 2010. 19(10), p.1815-1822.

[5] Inoue, $\mathrm{M}$ et al. Daily total physical activity level and total cancer risk in men and women: results from a large-scale population-based cohort study in Japan.
Japan Public Health Center based Prospective Study Group. Am J Epidemiol. 2008, 15; 168(4), p.391-403. [6] 竹中晃二 編集. 健康スポーツの心理学. 大修 館書店. 1998. (04), p.35

\section{[7] FITNESS BUSINESS}

http://www.fitnessclub.jp/business/date/history.html, (参照 2016-12-31).

[8] さよならエアロビクス. フィットネスジャー ナル. 2011. (299), p15, 25-26.

[9] 古宮昇. ヨガの心身の健康効果についての文 献リビュー. 大阪経大論集. 2008, 59(3), p.139-147 [10] 坂木佳寿美. ヨガの呼吸とからだへの影響. 体育の科学. 1999, 49, p382-387.

[11] 熊原秀晃ほか. ボクシングの運動様式を応用 した一過性運動が壮・中年者の感情に及ぼす影響. 体育学研究. 2014, 59, p251-261

[12] 木村慧心. ヨガとは何か一世界最古の統合的 健康実現法一. Aromatopia. 2002, 11, p.21-25

[13] 横山和仁ほか. 診断・指導に活か寸 POMS 事 例集. 金子書房. 2006.

[14] 慶応義塾大学病院 医療・健康情報サイト http://kompas.hosp.keio.ac.jp/contents/000315.html）， (参照 2017-01-6).

[15] 中村恭子ほか. 健康運動の継続意欲に及ぼす 心理的要因の検討ージョギングとエアロビックダ ンスの比較一. 順天堂大学スポーツ健康科学研究, 2004, 8, p2-12.

[16] 荒井弘和ほか. 一過性運動に伴う感情 : セル フ・エフィカシーとの関連および感情間の関連性. 体育学研究. 2010, 55, p.111-123.

[17] Raglin, J. S et al. State anxiety follow-ing20-min of bicycle ergometer exercise at selected intensities. Int J sports Med. 1996, 17(6), p.467-471.

[18] Steptoe, A et al. Acute effects of aerobic exercise on mood. Health Psychol. 1988, 7(4) p329-340.

[19] 竹中晃二ほか. 一過性運動の心理学的反応に 及ぼす特性不安および運動習慣形成の効果. 体育 学研究. 2002, 47(6), p579-592.

[20] 牛島一成ほか. 有酸素運動が体力および精神 状態に及ぼす長期的影響と短期的影響. 心身医. 1998, 38, p259-266.

[21] Ekkekakis, P et al. Acute aerobic exercise and affect: current status, problems and prospects regarding dose-response. Sports Med. 1999, 28, p.337-374. [22] Ainsworth, BE et al. Compendium of Physical 
Activities: a second update of Codes and MET values. Med Sci Sports Exerc. 2011, 43(8), p.1575-1581.

[23] Yoshihara, K et al. Effect of 12 weeks of yoga training on the somatization, psychological symptoms, and stress-related biomarkers of healthy women.

Biopsychosoc Med. 2014 Jan 3;8(1):1. doi:

10.1186/1751-0759-8-1.

\section{Abstract}

Objective of this study was to clarify acute influence of boxing exercise (BE) and Yoga on psychological state in middle aged women. The subjects were 40 middle aged women (20 in each program) who voluntarily participated in either class of BE program or Yoga program provided in local community. Psychological state was assessed using Profile of Mood States (POMS), composed of 6 subscales (Tension-Anxiety, Depression-Dejection, Anger-Hostility, Vigor, Fatigue, Confusion), before and after the class. The acute influence on the mood of each exercise program was examined by within group comparison of change using Wilcoxon test. Difference of change in the mood between the groups was examined by analysis of covariance using the change in the mood from before to after the class for the objective variable, groups for explanatory variable, and a value of mood before the class, age, and BMI for adjusting variables. As a result, the BE group showed significant positive within-group differences in the subscale of "Tension-Anxiety" and "Depression". The Yoga group showed significant positive changes in "Tension-Anxiety", "Depression", "Anger-Hostility", "Vigor", and "Confusion". The significant difference of change in the mood between the groups was observed in the subscale of "Anger-Hostility", which showed negative change in the BE group and positive change in the Yoga group. These results showed that the BE and Yoga programs, composed of different mode (dynamic or static) of exercise, brought an acute changes in the mood in the middle-aged women, but that the pattern of the change in profile of the mood was different by the mode and intensity of the exercise program.

（受付日：2017 年 1 月 9 日，受理日：2017 年 2 月 8 日）

\section{早川 洋子（はやかわ ようこ）}

現職 : 東京国際大学人間社会学部人間スポーツ学科 准教授

筑波大学大学院博士課程体育科学研究科運動生理学専攻単位取得退学.

順天堂大学医学部衛生学 博士 (医学)

筑波大学大学院で運動生理学をベースにした運動処方を学び，研究テーマは，身体活動をメインにした 人の健康づくり（公衆衛生学的見地から）及び，人と動物の絆を深め相互の福祉を図るヒューマン・ア ニマル・ボンド.

\section{主な著書 :}

健康科学 健康運動の実際 〜支援から実践まで〜

(分担執筆) 中高年期における健康運動：グループエクササイズ - 3つのエクササイズを中心に一. 金芳堂

Wellness Lifeウエルネスライフのすすめ

(分担執筆) 第 6 部 心と身体のヘルスケア 良い姿勢と動き。一般財団法人ウエルネスアカデミー編集委 員会 